\title{
Estrogen receptor $\beta$ expression and androgen receptor phosphorylation correlate with a poor clinical outcome in hormone-naïve prostate cancer and are elevated in castration-resistant disease
}

\author{
Tobias Zellweger, Susanne Stürm', Silvia Rey', Inti Zlobec ${ }^{2}$, Joel R Gsponer', \\ Cyrill A Rentsch ${ }^{1,3}$, Luigi M Terracciano', Alexander Bachmann ${ }^{3}$, Lukas Bubendorf ${ }^{1}$ \\ and Christian Ruiz ${ }^{1}$ \\ Department of Urology, St Claraspital, Basel, Switzerland \\ ${ }^{1}$ Institute for Pathology, University Hospital Basel, University of Basel, Schönbeinstrasse 40, 4031 Basel, Switzerland \\ ${ }^{2}$ Institute of Pathology, University of Bern, Bern, Switzerland \\ ${ }^{3}$ Department of Urology, University Hospital Basel, Basel, Switzerland
}

Correspondence should be addressed to C Ruiz

Email

christian.ruiz@unibas.ch

\begin{abstract}
Patients with advanced prostate cancer (PC) are usually treated with androgen withdrawal. While this therapy is initially effective, nearly all PCs become refractory to it. As hormone receptors play a crucial role in this process, we constructed a tissue microarray consisting of PC samples from 107 hormone-naïve (HN) and 101 castration-resistant (CR) PC patients and analyzed the androgen receptor $(A R)$ gene copy number and the protein expression profiles of $A R$, Serin210-phosphorylated $A R\left(p A R^{210}\right)$, estrogen receptor $(E R) \beta, E R \alpha$ and the proliferation marker Ki67. The amplification of the $A R$ gene was virtually restricted to $C R P C$ and was significantly associated with increased AR protein expression $(P<0.0001)$ and higher tumor cell proliferation $(P=0.001)$. Strong AR expression was observed in a subgroup of HN PC patients with an adverse prognosis. In contrast, the absence of AR expression in CR PC was significantly associated with a poor overall survival. While $p A R^{210}$ was predominantly found in CR PC patients $(P<0.0001), \mathrm{pAR}^{210}$ positivity was observed in a subgroup of HN PC patients with a poor survival $(P<0.05)$. Epithelial ER $\alpha$ expression was restricted to CR PC cells $(9 \%)$. $E R \beta$ protein expression was found in $38 \%$ of both HN and CR PCs, but was elevated in matched CR PC specimens. Similar to $P A R^{210}$, the presence of ER $\beta$ in $H N$ patients was significantly associated with an adverse prognosis $(P<0.005)$. Our results strongly suggest a major role for $\mathrm{PAR}^{210}$ and ER $\beta$ in HN PC. The expression of these markers might be directly involved in CR tumor growth.
\end{abstract}

\section{Key Words \\ - prostate cancer \\ - castration resistance \\ - hormone receptors \\ - hormone naïve \\ - androgen receptor \\ - estrogen receptor}




\section{Introduction}

Prostate cancer (PC) is the most frequently diagnosed cancer among males in developed countries (Jemal et al. 2011). During the last few decades, mortality from PC in developed countries has decreased, mainly due to earlier detection and improved treatment options. However, PC still accounts for $9 \%$ of the total cancer deaths (Jemal et al. 2011).

At initial diagnosis, PCs depend on androgens for their growth and are usually referred to as hormone-naïve (HN) or untreated PCs. The response to androgens is mediated by the androgen receptor (AR) protein, which upon binding of the ligand in the cytosol dissociates from the inhibitory heat shock proteins, gets phosphorylated and translocates to the nucleus (Brinkmann et al. 1999, Feldman \& Feldman 2001). The active AR homodimers are able to bind to androgen-response elements (AREs) and thus lead to the transcriptional activation of AR target genes, such as the prostate-specific antigen (PSA), as well as other genes that contribute to cell survival and growth (e.g. CDK1 and CDK2) (Feldman \& Feldman 2001). This androgen dependency is the rationale behind androgen deprivation therapy (ADT) in patients with advanced PC. This therapy is effective in most of the patients and thus leads to tumor regression. However, after a few months or years, nearly all PCs overcome the effect of this ablation and recur as castration-resistant (CR) PCs. The therapeutic options in CR PC are very limited. It is, therefore, of utmost importance to understand the mechanisms that are responsible for this progression. One of the mechanisms comprises an increased sensitivity to the remaining low levels of androgens, for example, by overexpression of the AR due to genomic amplification (Visakorpi et al. 1995) or by decreased ligand specificity because of mutations in the ligand-binding domain of the $A R$ gene (Wilding et al. 1989, Taplin et al. 1995). Furthermore, direct phosphorylation of the AR protein by MAPK, AKT and tyrosine receptor kinases has also been shown to increase AR sensitivity (Culig 2004, Edwards \& Bartlett 2005, Guo et al. 2006). Until now, 17 phosphorylation sites of the AR have been described in the literature (reviewed in Anbalagan et al. (2012)). In particular, the phosphorylation of serine residues 210 and $790\left(\mathrm{pAR}^{210}\right.$ and $\mathrm{pAR}^{790}$ ) by the PI3K/AKT pathways can result in the modulation of the stability of the AR protein (Lin et al. 2003). Furthermore, it has been suggested that the phosphorylation of the AR at serine residue 210 by the AKT kinase may sensitize the AR protein to low circulating levels of androgens and thus promote progression to castration resistance (Rochette-Egly 2003, Edwards \& Bartlett 2005). Recently, an increase in the $\mathrm{pAR}^{210}$ level has been reported in the transition from $\mathrm{HN}$ to CR PC and elevated $\mathrm{pAR}^{210}$ levels in $\mathrm{CR}$ PC have been reported to be associated with a poor clinical outcome (McCall et al. 2008).

Although PC research has been 'androgen' dominated, evidence has accumulated that estrogens and their corresponding receptors (ER $\alpha$ and $\mathrm{ER} \beta$ ) can significantly influence PC growth and progression. Both receptors are expressed in the adult prostate, but whereas ER $\alpha$ expression appears to be restricted to the stromal compartment, ER $\beta$ is present in both the epithelial cells and, to a lesser extent, in the stromal compartment (reviewed in Carruba (2007)). Especially, the role of the latter has been controversially discussed: the loss of ER $\beta$ was shown to correlate with disease progression (Latil et al. 2001) and to induce epithelial-mesenchymal transition (Mak et al. 2010) and higher expression levels of $\operatorname{ER} \beta$ were associated with a poor outcome in PC patients (Nanni et al. 2009).

In order to study the role of the AR and the two estrogen receptors $\mathrm{ER} \alpha$ and $\mathrm{ER} \beta$ in the context of PC progression, we performed a comprehensive analysis of their expression (AR, ER $\alpha$ and ER $\beta$ ), phosphorylation $\left(\mathrm{pAR}^{210}\right)$ and genomic amplification status $(A R)$ in a cohort of 202 patients with HN or CR PC. Here, we demonstrate that $\mathrm{pAR}^{210}$ is increased in CR PC and that high levels of $\mathrm{AR}, \mathrm{ER} \beta$ and $\mathrm{pAR}^{210}$ in $\mathrm{HN}$ PC correlate with a poor clinical outcome.

\section{Materials and methods}

\section{Tissue microarray and patients}

The use of clinical specimens for the construction of the crTMA was approved by the ethical committee of the University of Basel and the University Hospital of Basel. The crTMA was manufactured as described previously (Kononen et al. 1998). Briefly, tissue cylinders with a diameter of $0.6 \mathrm{~mm}$ were punched from the 'donor' tissue blocks containing the specimens from transurethral resections of the prostate (TURPs) using a home-made, semi-automatic robotic precision instrument. From each specimen, three cores were arrayed. The composition of the crTMA is described in detail in Supplementary Table 1, see section on supplementary data given at the end of this article. All specimens analyzed in this study

Published by Bioscientifica Ltd. 
were from tissue biopsies obtained by transurethral resection. Castration resistance was defined as locally obstructive recurrence and/or PSA recurrence during ADT. ADT was surgical (orchiectomy) or medicamentous (GNRH agonists and/or antiandrogens). Median followup time for all patients ( $\mathrm{HN}$ and CR) was 22 months. Median time of ADT until surgery of CR recurrence was 49 months. Median time of transition from HN to CR disease for patients $(n=36)$ with matched specimens was 34 months.

\section{Immunohistochemistry}

Immunohistochemistry (IHC) was performed according to standard indirect immunoperoxidase procedures. The primary antibody was omitted for negative controls. All slides were read manually by an experienced pathologist (L B). The AR antibody (M3562, Dako, Carpinteria, CA, USA) was used in a 1:200 dilution (pretreatment: microwave, $98^{\circ} \mathrm{C}, 60 \mathrm{~min}$; citrate buffer $10 \mathrm{mM}, \mathrm{pH} 6$ ). The ER $\alpha$ antibody (Clone SP1, \#790-4324, Ventana Medical Systems, Tucson, AZ, USA) was used prediluted (pretreatment: CC1 mild) and staining was performed using the iView DAB detection kit (Ventana Medical Systems). ER $\beta$ (NCL-ER-beta, Leica, Wetzlar, Germany) was used in a 1:50 dilution after pretreatment (microwave, $98^{\circ} \mathrm{C}, 30 \mathrm{~min}$; citrate buffer $10 \mathrm{mM}, \mathrm{pH}$ 6). Ki67 incubations (M7240, Dako) were performed as described previously (Zellweger et al. 2003). For the detection of $\mathrm{pAR}^{210}$, the antibody IMG-561 (Imgenex, San Diego, CA, USA) was used in a 1:50 dilution (pretreatment: pressure cooker, $120^{\circ} \mathrm{C}, 5 \mathrm{~min}$; citrate buffer $10 \mathrm{mM}, \mathrm{pH}$ 6). Images were obtained using a Zeiss AXIO Imager.A1 microscope (Zeiss, Jena, Germany) equipped with an AxioCam (Zeiss) and the AxioVision 4.6 software (Zeiss).

\section{Fluorescence in situ hybridization}

For proteolytic slide pretreatment, a commercial kit was used (Paraffin pretreatment reagent kit, Vysis, Downers Grove, IL, USA). A Spectrum Orange-labeled probe specific for the $A R$ gene was used (Xq12 probe, Vysis) along with the Spectrum Green-labeled centromere X probe (Vysis). Hybridization was performed as described previously (Ruiz et al. 2006). A tumor was considered amplified if the ratio of $A R$ gene copy number to centromere $\mathrm{X}$ was $>2.0$. Images were obtained using a Zeiss Axioplan 2 fluorescence microscope (Zeiss) equipped with an ISIS digital camera (MetaSystems, Altlussheim, Germany).

\section{Cut-offs, data analysis and statistics}

For the protein expression analysis of AR, Ki67, ER $\alpha, \mathrm{ER} \beta$ and $\mathrm{pAR}^{210}$, the percentage of positive tumor cells was noted and used as a score. In general, the nuclear staining intensity was uniform and unequivocal, and thus a quantification of the nuclear staining was not performed. For dichotomous categorization, ROC curve analyses were performed (see Supplementary Table 3, see section on supplementary data given at the end of this article for the cut-off values). In addition, for AR analysis (see Results), a composite score $(0-300)$ was calculated by multiplying the maximal recorded staining intensity (1-3) with the percentage of positive tumor cells (Ruiz et al. 2010). For correlation studies between different markers, every evaluable spot was considered for the analysis; that is, the analysis was performed on a 'spot-by-spot' basis. All other analyses (i.e. with clinical data, such as treatment status, cM, cT and survival data) were performed on a 'one-value-per-specimen' basis, thereby considering only one value per specimen. If more than one spot/value per specimen was evaluable, the spot with the maximal score was included in the analysis.

Statistical analysis was performed with the software JMP 8 (SAS Institute, Inc., Cary, NC, USA). Differences between two groups were analyzed with the Wilcoxon Rank Sum test; differences between more than two groups were analyzed using the Kruskal-Wallis Rank Sum test. Survival curves were plotted using the Kaplan-Meier method and differences were assessed using the log-rank test. $P$ values $<0.05$ were considered as statistically significant.

\section{Results}

\section{Different status of hormone receptors in HN and CR PCs}

We constructed a tissue microarray (TMA) from 231 TURPs from a total of 202 patients treated with advanced, locally obstructive PC in order to study the role of hormone receptors during the progression from HN to CR PC (see Supplementary Table 1 for a summary). Clinical follow-up data were available for 227 of the 231 patients. Median overall survival time for patients with HN PC and CR PC was 3.7 years and 10.3 months respectively. Survival analysis of basic clinical or pathological features is summarized in Supplementary Figure 1. As expected, Gleason pattern was a strong predictor of overall survival in both HN and CR PCs. Furthermore, cM stage and 'age at surgery' had prognostic significance in patients with HN PC.

Published by Bioscientifica Ltd. 

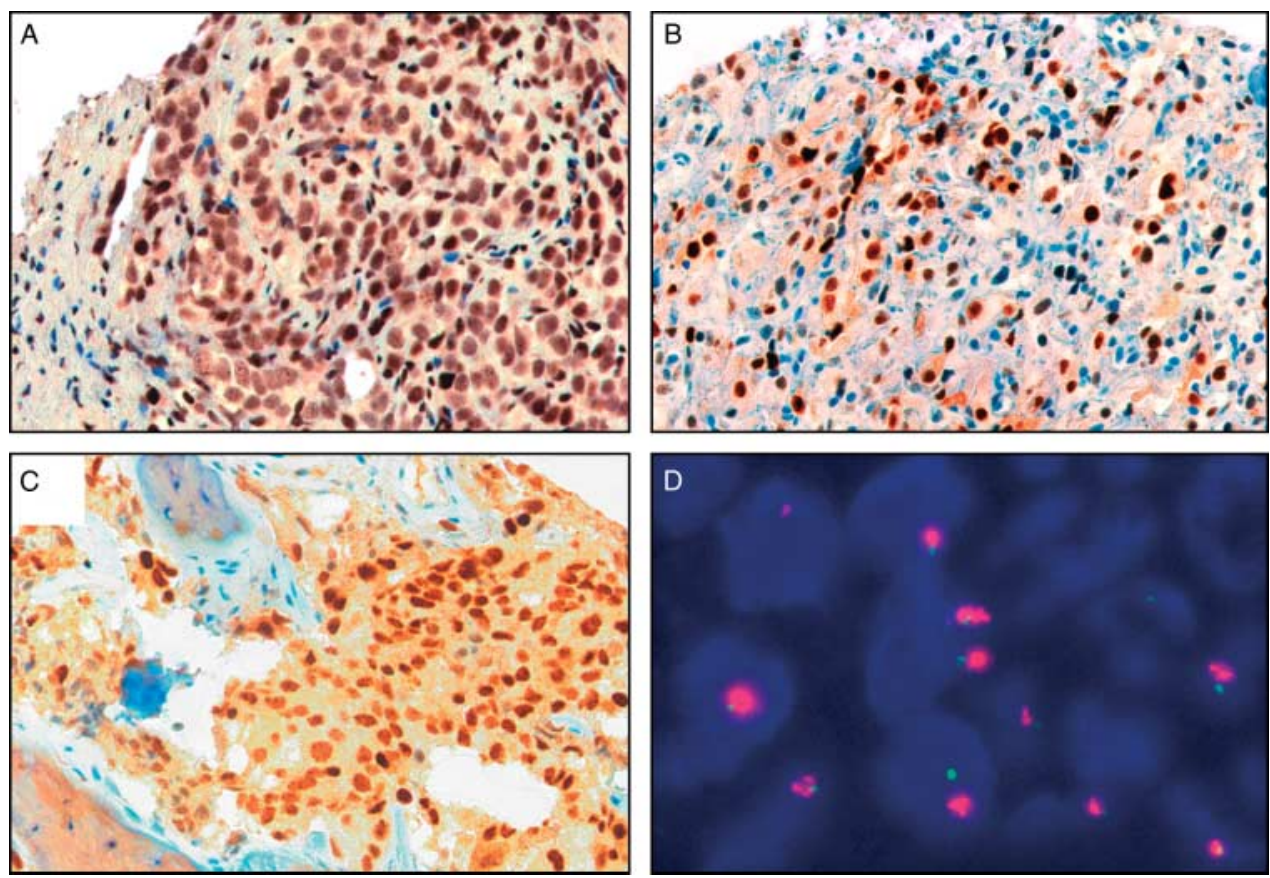

Figure 1

Representative images of prostate carcinomas from the crTMA.

(A) Erß-positive CR PC. (B) Era-positive CR PC. (C) Bone metastasis with

We assessed the $A R$ gene copy number by fluorescence in situ hybridization (FISH) and the protein expression levels of AR, Ser210 phosphorylated AR (pAR), ER $\alpha$ and ER $\beta$ by IHC (Fig. 1). Of note, the antibody used for ER $\beta$ protein detection in this study is specific for the wild-type form (the so-called ER $\beta 1$ ). We evaluated the nuclei of epithelial tumor cells present on the arrayed specimens and applied a scoring system from 0 to 100 representing the percentage of stained tumor cells irrespective of staining intensity (see the Materials and methods section for further details). In addition, for AR, we calculated a composite score that takes into consideration the nuclear intensity (see the Materials and methods section). We found extensive AR expression (maximal score of 100) in all BPHs and in $90 \%$ of the PCs, independent of their a diffuse expression of phosphorylated $A R\left(p A R^{210}\right)$. (D) Example of a CR PC with amplification of the $A R$ gene (red signals).

hormonal treatment status (Table 1). AR mean expression score (percentage) did not vary between the HN and CR PC samples, but consideration of the nuclear staining intensity revealed higher AR protein amounts in the CR PC samples than in the HN PC samples $(P<0.01$, Supplementary Table 6 , see section on supplementary data given at the end of this article). Furthermore, the CR PC samples showed a significantly more frequent phosphorylation of the AR protein $(P<0.0001)$. The amplification of the $A R$ gene was detected in $42 \%$ of the CR PC samples, but was present in only $1 \%$ (1 of 109) of the HN PC samples $(P<0.0001$, Table 2$)$. In contrast to the AR, the expression pattern of the ERs in epithelial cells was more multifaceted. The expression of ER $\beta$ was detected in 38\% of the PC samples (data not shown), but without

Table 1 Overview of the hormone receptor status of the prostate samples on the crTMA. Summary of the expression status of the hormone receptors across different stages of prostate disease.

\begin{tabular}{lccc}
\hline & $\boldsymbol{n}(\mathrm{BPH} / \mathrm{HN} / \mathrm{CR})$ & & BPH mean \pm s.D. \\
\cline { 1 - 1 } $\mathrm{AR}(\mathrm{IHC})$ & $12 / 106 / 112$ & & $100.0 \pm 0$ \\
$\mathrm{pAR}$ & $12 / 105 / 111$ & & $79.2 \pm 18.3$ \\
$\mathrm{ER} \alpha$ & $12 / 112 / 110$ & & $0.4 \pm 1.4$ \\
$\mathrm{ER} \beta$ & $12 / 99 / 109$ & & $100.0 \pm 0$ \\
\hline & &
\end{tabular}

\begin{tabular}{c} 
HN mean \pm s.D. \\
\hline $95.0 \pm 17.4$ \\
$38.9 \pm 36.6$ \\
$0 \pm 0.1$ \\
$35.3 \pm 39.2$
\end{tabular}

\begin{tabular}{c} 
CR mean \pm s.D. \\
\hline $94.0 \pm 23.0$ \\
$62.1 \pm 37.4$ \\
$1.4 \pm 4.9$ \\
$36.8 \pm 40.2$ \\
\hline
\end{tabular}

\begin{tabular}{c}
$\boldsymbol{P}$ value $^{\mathrm{a}}$ \\
\hline 0.347 \\
$<0.0001$ \\
0.0008 \\
0.759
\end{tabular}

${ }^{a}$ Wilcoxon Rank Sum test between HN and CR. 
Table 2 Overview of the androgen receptor gene status of the prostate samples on the crTMA.

\begin{tabular}{lcc}
\hline SR (FISH) & Status & BPH $\boldsymbol{n}(\%)$ \\
\hline Normal & $12(100)$ \\
Amplified & 0 \\
\hline
\end{tabular}

\begin{tabular}{c}
\hline $\mathbf{H N} \boldsymbol{n}(\%)$ \\
\hline $108(99)$ \\
$1(1)$ \\
\hline
\end{tabular}

\begin{tabular}{cc}
\hline CR $\boldsymbol{n}(\%)$ & $\boldsymbol{P}$ value $^{\mathrm{a}}$ \\
\hline $68(58)$ & $<0.0001$ \\
$49(42)$ & \\
\hline
\end{tabular}

${ }^{\mathrm{a}}$ Pearson between $\mathrm{HN}$ and $\mathrm{CR}$.

differential expression between the HN and CR PC samples $(P=0.759$, Table 1$)$. Interestingly, in a defined set of matched $\mathrm{HN}$ and CR samples (see below), ER $\beta$ was elevated in the CR PC samples (Supplementary Table 4, see section on supplementary data given at the end of this article). $\mathrm{ER} \alpha$, instead, was only detectable in $9 \%$ of the CR PC samples and was completely absent in the HN PC samples $(P<0.0008$, Table 1$)$. We further investigated the co-expression of these hormone receptors (Table 3). As expected, the highest correlation was detected between AR and $\mathrm{pAR}^{210}$, both in the HN and CR PC samples.

\section{Hormone receptor status and association with clinico-pathological features}

We next investigated the association between hormone receptor status and clinico-pathological features, such as cM and cT stages (Supplementary Table 2, see section on supplementary data given at the end of this article), and Gleason pattern (Supplementary Table 7). The prevalence of $A R$ gene amplification increased significantly with higher cT stage $(P=0.017$, Supplementary Table 2$)$ and ER $\beta$ expression was slightly higher in metastatic CR PC samples $(P<0.05)$. In contrast, the expression of ER $\beta$ and the expression and phosphorylation of the AR in the HN PC samples were strongly associated with a higher Gleason pattern $(P<0.05$ each, Supplementary Table 7$)$. No other relevant associations were found between the expression of the hormone receptors and the $\mathrm{cM}$ or cT stage.

\section{Status of hormone receptors in $A R$-non-amplified and -amplified CR PCs and correlation with tumor cell proliferation}

In order to evaluate the impact of the amplification of the $A R$ gene on the presence of the hormone receptors, we stratified the samples from the CR patients based on their $A R$ gene amplification status and analyzed the expression of the hormone receptors in these two groups. Although AR protein expression was observed in most of the PC samples, it was significantly more extensive in the CR PC samples with $A R$ amplification as opposed to those without $(P<0.0001$, Fig. 2$)$. Concordantly, higher prevalence of phosphorylated AR protein was observed in the $A R$-amplified samples than in the non-amplified ones. In order to evaluate the role of the hormone receptors in tumor cell proliferation, we analyzed Ki67 expression in the same samples (Fig. 3, Supplementary Table 8, see section on supplementary data given at the end of this article). In contrast to the HN PC samples, in the CR PC samples, higher Ki67 staining was significantly associated with a worse outcome ( $P=0.0015$, Fig. 3B). This analysis

Table 3 Correlation of the expression of the different hormone receptors stratified into HN and CR PC.

\begin{tabular}{|c|c|c|c|c|}
\hline & AR $(\mathrm{IHC})$ & PAR & $\operatorname{ER} \alpha$ & $\operatorname{ER} \beta$ \\
\hline \multicolumn{5}{|c|}{ Hormone naïve } \\
\hline $\mathrm{AR}(\mathrm{IHC})$ & $1^{\mathrm{a}}$ & & & \\
\hline $\mathrm{pAR}$ & $0.30 *$ & 1 & & \\
\hline $\mathrm{ER} \alpha$ & 0.03 & 0.04 & 1 & \\
\hline $\mathrm{ER} \beta$ & $0.17^{\dagger}$ & $0.24^{\ddagger}$ & 0.28 & 1 \\
\hline \multicolumn{5}{|c|}{ Castration resistant } \\
\hline AR (IHC) & 1 & & & \\
\hline $\mathrm{pAR}$ & 0.41 * & 1 & & \\
\hline $\mathrm{ER} \alpha$ & -0.01 & 0.03 & 1 & \\
\hline $\mathrm{ER} \beta$ & 0.03 & $0.21^{\S}$ & 0.04 & 1 \\
\hline
\end{tabular}

Only significant $P$ values are denoted. ${ }^{*} P<0.0001 ;{ }^{\dagger} P=0.009 ;{ }^{\ddagger} P=0.0006 ;{ }^{5} P=0.0013$

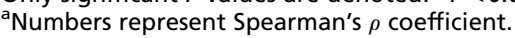

http://erc.endocrinology-journals.org DOI: 10.1530/ERC-12-0402
(C) 2013 Society for Endocrinology Printed in Great Britain
Published by Bioscientifica Ltd 


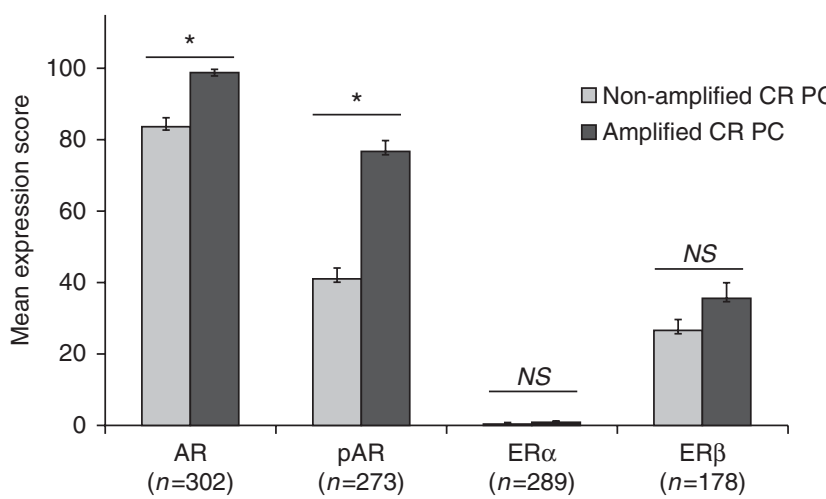

Figure 2

Hormone receptor expression and $A R$ gene amplification in CR PC. $A R$ amplified CR PCs show higher levels of $A R$ and $p A R^{210}$ by immunohistochemistry. Error bars denote S.E.M.; $*:<0.0001$; NS, not significant. Statistical analysis: Kruskal-Wallis Rank Sum test.

also revealed the presence of three Ki67 categories with a distinct outcome: low $(<5 \%)$, medium $(5-50 \%)$ and high ( $>50 \%)$. However, almost all samples fell into the first two categories (99 and $92 \%$ for $\mathrm{HN}$ and CR respectively). In these cases, expression of the AR in HN PC, as well as in CR PC, was strongly associated with increased tumor cell proliferation $(P=0.0007$ and $P=0.006$ respectively). The same was true for the expression of ER $\beta$ in the HN PC samples $(P=0.006)$ and to a lesser extent for the amplification of the $A R$ gene $(P=0.049)$. Among the CR PC samples, those with high Ki67 staining ( $>50 \%)$ were characterized by very low levels of AR expression and phosphorylation (Supplementary Table 8).

\section{Prognostic role of the hormone receptor status}

We next investigated the prognostic role of the hormone receptor status in patients with HN and CR PCs. Overall survival analysis revealed distinct prognostic roles for the hormone receptors analyzed in this study (Fig. 4, Supplementary Table 3). In the HN PC samples, the phosphorylation of the AR as well as the expression of $\operatorname{ER} \beta$ was significantly associated with a poor overall survival $(P<0.05$ both). In the CR PC samples, only ER $\alpha$ protein expression seemed to classify a small group of patients with a distinct (probably better) prognosis. However, a larger number of positive cases are needed in order to properly confirm a potential prognostic role of this finding. Interestingly, the analysis of stromal positivity, which was not a primary aim of this study, revealed additional ER $\alpha$ positivity in $19 \mathrm{HN}$ and $21 \mathrm{CR}$ prostate samples (data not shown). The presence of this stromal
ER $\alpha$ expression was associated with a better overall survival of CR PC patients ( $P=0.003$, Fig. 4$)$. We were not able to detect a prognostic role for the expression of the AR protein with the above-applied scoring system (data not shown); probably, the lack of a prognostic effect was due to the large number of AR-positive PCs classified with the maximal score (>90\%). Therefore, we included the nuclear staining intensity in the calculation of the AR score (composite score; see the Materials and methods section for more details) and were thus able to perform a more subtle categorization (absent, low, moderate and strong). This four-tiered categorization revealed a poor overall survival for patients with strongly AR-expressing HN PCs $(P=0.02$, Fig. 4). In contrast, in the CR PC patients, the complete absence of AR protein expression characterized a small subgroup of patients with a worst prognosis $(P=0.015$, Fig. 4). If all markers that were
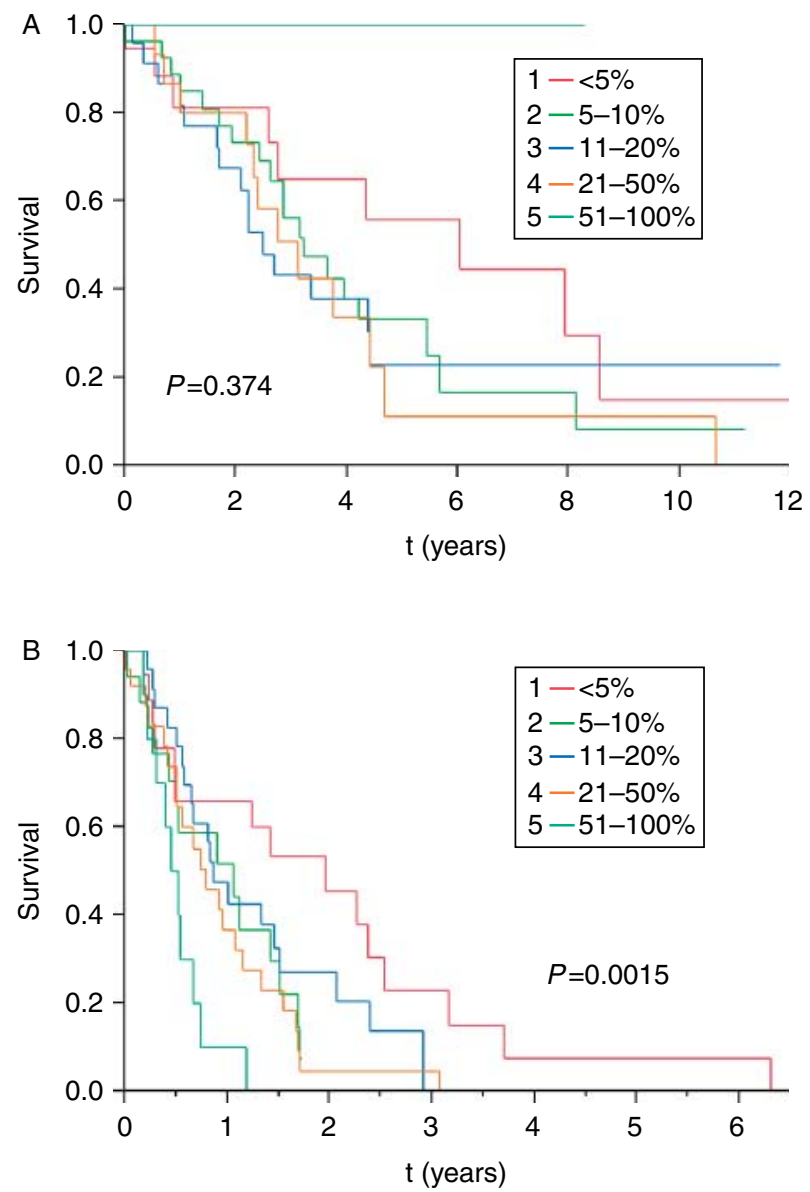

Figure 3

Overall survival analysis of different Ki67 groups. In castration-resistant (B) but not in hormone-naïve (A) PC, increased tumor cell proliferation (Ki67 expression) is significantly associated with a worse overall survival. Numbers denote the percentage of positive tumor cells. 

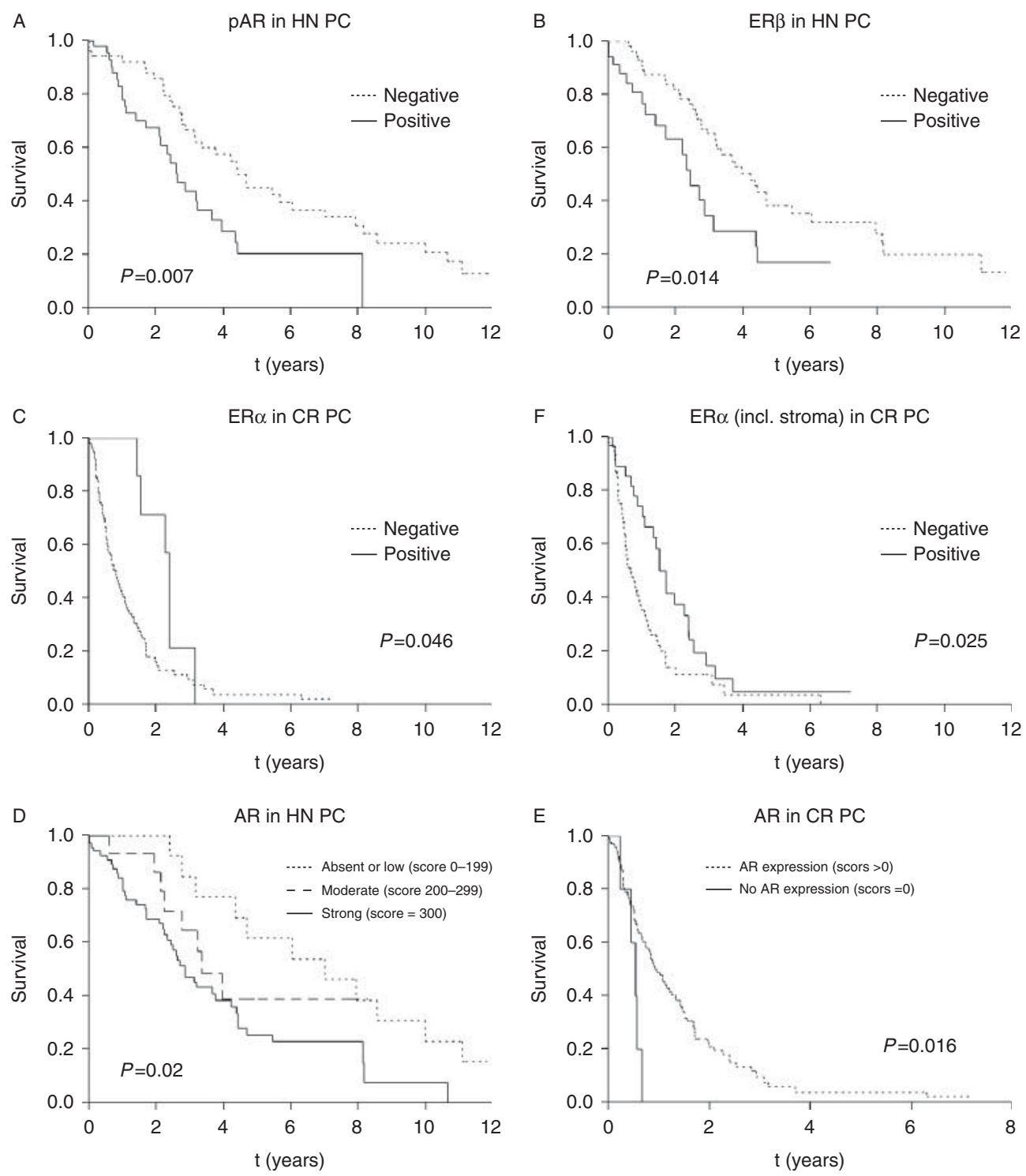

Figure 4

Overall survival analysis and hormone receptor status. Patients with higher levels of $A R(D), p A R(A)$ or $\operatorname{ER} \beta(B)$ in hormone-naïve PCs have a worse

overall survival. In CR PCs, the loss of ER $\alpha$ ( $C$ and $F)$ and $A R(E)$ was correlated with a worse overall survival.

significant in the univariate analysis (pAR, ER $\beta, A R$, Gleason pattern and $\mathrm{ER} \alpha, \mathrm{AR}, \mathrm{Ki} 67$, and Gleason pattern for $\mathrm{HN}$ and CR PCs respectively) were subjected to a multivariate analysis, only the Gleason pattern remained an independent prognostic factor (data not shown).

\section{Hormone receptor status in a defined set of matched HN and CR samples}

The crTMA used in this study comprised a unique set of 36 matched PC samples from the same patients before and after hormonal ablation therapy. Patient cohort and the resulting hormone receptor status are summarized in Supplementary Table 4. The comparison between HN and CR PC samples in the matched specimens revealed results similar to the ones obtained when the complete cohort (231 TURP samples) was considered for the analysis: the amplification of the $A R$ gene in $40 \%$ of the CR PC samples (14/35), increase in AR phosphorylation after recurrence, and restriction of epithelial ER $\alpha$ expression to CR PC. Only the ER $\beta$ increase in matched CR PC specimens was not detectable in the analysis of the

Published by Bioscientifica Ltd. 
Table 4 Correlation analysis between the time to recurrence and the hormone receptor expression score of hormone-naïve PC.

\begin{tabular}{|c|c|c|}
\hline & Correlation coefficient ${ }^{a}$ & $P$ value \\
\hline $\mathrm{AR}(\mathrm{IHC})$ & -0.38 & 0.03 \\
\hline pAR & -0.42 & 0.013 \\
\hline $\mathrm{ER} \alpha$ & - & - \\
\hline ER $\beta$ & -0.28 & 0.137 \\
\hline
\end{tabular}

${ }^{a}$ Correlation coefficient corresponds to Spearman's $\rho$.

whole cohort. Furthermore, when staining intensity was considered in the expression analysis, it was observed that AR protein levels significantly increased after recurrence.

We further utilized this matched sample cohort in order to investigate a potential correlation between the expression of the hormone receptors in HN PC and the time until recurrence as CR PC after the initiation of hormonal ablation therapy. Intriguingly, higher expression and phosphorylation of the AR were significantly associated with earlier time to recurrence $(P<0.05$ both, Table 4). This finding is in line with the results from the overall survival analysis (Fig. 4), in which we observed that higher expression or phosphorylation of the AR protein in HN PC patients was strongly associated with a poor overall survival.

\section{Discussion}

Despite the efforts made in basic and clinical research in the last few decades, the mechanisms that drive the progression of HN PC to CR PC have not been completely elucidated. To address these mechanisms, we constructed a tissue microarray (TMA) from TURPs originating from $\mathrm{HN}$ (before ADT) and CR (recurrence during ADT) prostate tumors and studied the protein expression of the hormone receptors $A R, E R \alpha$ and $E R \beta$ and, in addition, the phosphorylation and the genomic (amplification) status of AR.

In this study, we showed that AR protein expression is present in almost all HN and CR PCs, whereas genomic amplification is virtually restricted to CR PC. The latter finding is commonly accepted, but the expression patterns of the AR in HN and CR PCs have been controversially discussed in the literature (Linja et al. 2001, MacKenzie et al. 2012). We showed that whereas most of the PC cells, independent of the ADT status, express the AR protein, $\mathrm{CR}$ PC cells express it at higher levels. Furthermore, the amplification of the $A R$ gene was associated with very high AR expression. These findings further support the relevance of increasing AR expression as a response to the lower levels of androgens after ADT, possibly in order to sensitize cells to lower ligand concentrations (Koivisto et al. 1997, Waltering et al. 2009, Urbanucci et al. 2012). The high percentage of $A R$ amplification (42\%) in CR PC and the positive association with proliferation emphasize the importance of an activated AR pathway in CR disease.

High expression levels of the AR protein in patients treated with radical prostatectomy before ADT have been associated with worse overall and disease-specific survival and shorter time to disease relapse (reviewed in Donovan et al. $(2008,2010)$ and Hodgson et al. (2012)). We showed a similar finding for patients with locally obstructive HN PC treated by palliative TURP. This was not true for patients with CR PC where we identified a small proportion $(n=6)$ of highly aggressive cancers without detectable AR protein expression. Since three of these six AR-negative CR PCs were classified as neuroendocrine carcinomas, it is very likely that neuroendocrine transdifferentiation in these tumors occurred as a consequence of AR repression (Jongsma et al. 2000, Wright et al. 2003, Yuan et al. 2006).

Whereas the exact functions of the different AR phosphorylation sites have not been elucidated yet, the phosphorylation of serine $210\left(\mathrm{pAR}^{210}\right)$ has been suggested to be involved in the progression to castration resistance (Rochette-Egly 2003, Edwards \& Bartlett 2005, McCall et al. 2008). In the present study and similar to McCall et al. (2008), we observed an increase in $\mathrm{pAR}^{210}$ in the progression from HN to CR PC $(P<0.01)$. In addition, we also found a strong correlation between increased $\mathrm{pAR}^{210}$ and high serum PSA levels in HN PC $(P<0.01$, Supplementary Table 5 , see section on supplementary data given at the end of this article). Our findings suggest that in HN PC, increased $\mathrm{pAR}^{210}$ levels lead to an activation of AR target genes (such as PSA) and that this phosphorylation might condition tumor cells for survival under active ADT. Concordantly, HN PCs with increased pAR ${ }^{210}$ in the matched patient cohort were characterized by a significant shorter time to recurrence. In contrast to McCall et al., we observed an adverse overall survival for patients with increased $\mathrm{pAR}^{210}$ in $\mathrm{HN}$ PC, but not in patients with CR PC. This could be explained by the different inclusion criteria and distinct definition of recurrence: in our study, we did not restrict our HN cohort to samples from patients who subsequently relapsed from CR PC. Furthermore, recurrence was not exclusively defined on rises in PSA levels (biochemical recurrence), but mainly defined on the presence of symptomatic locally obstructive disease under ADT.

Published by Bioscientifica Ltd. 
A further aim of this study was the analysis of the expression of the estrogen receptors ER $\alpha$ and ER $\beta$ in the progression to CR PC. Despite the historically prominent role of estrogens as standard treatment for PC, robust data about their expression and impact on progression are scarce (Huggins \& Hodges 1972, Cox \& Crawford 1995). Whereas little is known about ER $\alpha$ in this context, several findings on the potential good and bad roles of ER $\beta$ in PC have been reported. ER $\beta$ is mainly being considered as antiproliferative and potentially tumor suppressive, and the loss of ER $\beta$ expression has been associated with the progression to castration resistance (reviewed in Bonkhoff \& Berges (2009) and Nelles et al. (2011)). This is supported by functional data where ER $\beta$ downregulation in PC3 cells resulted in increased migration and invasion (Mak et al. 2010). Furthermore, ER $\beta$ has been suggested as an indirect repressor of VEGFA transcription and as an inhibitor of the transition to an invasive phenotype. Interestingly, our data point toward the other direction, at least in the context of progression to CR disease. We showed that increased ER $\beta$ expression in HN PCs is associated with a higher Gleason pattern and increased proliferation. In the matched patient cohort (before and during ADT), more than half of the patients (15 of 27) showed a significant increase in ER $\beta$ expression after progressing to castration resistance. Furthermore, HN PC patients whose tumors have higher ER $\beta$ levels are characterized by a worse overall survival. In contrast to the above-mentioned reports, our data advocate for a more tumor-promoting role of ER $\beta$, at least in the context of progression to castration resistance. Similar findings were described by Nanni et al. (2009); they found an association of ER $\beta$ expression with a shorter disease-specific survival in patients with clinically localized HN prostate tumors. Most recently, a positive correlation between ER $\beta$ and Cyclin D1, a protein with a known pro-proliferative function, has been described in HN patients (Nakamura et al. 2012). Altogether, these data advocate for a more prominent role of ER $\beta$ in the progression to castration resistance as thought previously. Whereas ER $\beta$ signaling might be protective at an early stage of prostate carcinogenesis, a switch during progression cannot be precluded. In this context, it is also worth discussing the benefit of using phytoestrogens, a group of plant compounds with structural similarity to $17 \beta$-estradiol, in patients with ER $\beta$-positive PC. Further studies are needed in order to properly define the potential use of specific ER $\beta$ antagonists or inhibitors during progression to CR disease in patients characterized by a high expression of ER $\beta$ protein.
There are only a few controversial reports on the role and expression of ER $\alpha$ protein in PC (Bonkhoff et al. 1999, Leav et al. 2001, Celhay et al. 2010). Whereas Bonkhoff et al. (1999) described an increased $E R \alpha$ protein expression with higher Gleason grade and highest expression in hormonerefractory carcinomas, others were only able to detect its expression in very few carcinomas (Leav et al. 2001). Most recently, Celhay et al. (2010) did not find a differential expression of $\mathrm{ER} \alpha$ between $\mathrm{HN}$ and CR PCs, but reported a survival advantage for ER $\alpha$-positive CR PC patients. Here, we detected epithelial ER $\alpha$ expression in 1\% (1/112) and $12 \%(13 / 109)$ of the HN and CR PC samples. This differential expression between $\mathrm{HN}$ and CR PC samples was less pronounced if $\mathrm{ER} \alpha$ positivity of both the stromal and epithelial compartments was included in the analysis (18 and 30\% of the HN and CR PC samples respectively). The latter stratification revealed a significantly better outcome for CR PC patients with either stromal or epithelial ER $\alpha$ expression. However, larger numbers of specimens and especially functional and molecular studies are needed in order to decipher the roles of $\mathrm{ER} \alpha$, its underlying signaling mechanism in the epithelial and stromal cells of PC tissue and its impact on tumor growth.

In summary, we showed that $\mathrm{ER} \alpha$ and $\mathrm{pAR}^{210}$ are differentially expressed in HN and CR PCs and that high levels of $A R, E R \beta$ and $p A R^{210}$ in HN PC correlate with a poor clinical outcome. We further identified a subpopulation of AR-negative CR PC patients with a highly aggressive behavior. Further studies including the genomic and transcriptomic analyses of matched PC samples (HN vs CR PC) will provide novel insights into the underlying pathways important for sustaining tumor growth in CR PC.

\section{Supplementary data}

This is linked to the online version of the paper at http://dx.doi.org/10.1530/ ERC-12-0402.

\section{Declaration of interest}

The authors declare that there is no conflict of interest that could be perceived as prejudicing the impartiality of the research reported.

\section{Funding}

This work was supported by the Krebsforschung Schweiz (KFS-02780-02-2011).

\section{Acknowledgements}

We thank Thuy Nguyen, Sandra Schneider, Petra Hirschmann and Barbara Ruch for their excellent technical support.

Published by Bioscientifica Ltd. 


\section{References}

Anbalagan M, Huderson B, Murphy L \& Rowan BG 2012 Post-translational modifications of nuclear receptors and human disease. Nuclear Receptor Signaling $\mathbf{1 0}$ e001.

Bonkhoff H \& Berges R 2009 The evolving role of oestrogens and their receptors in the development and progression of prostate cancer. European Urology 55 533-542. (doi:10.1016/j.eururo.2008.10.035)

Bonkhoff H, Fixemer T, Hunsicker I \& Remberger K 1999 Estrogen receptor expression in prostate cancer and premalignant prostatic lesions. American Journal of Pathology 155 641-647. (doi:10.1016/S00029440(10)65160-7)

Brinkmann AO, Blok LJ, de Ruiter PE, Doesburg P, Steketee K, Berrevoets CA \& Trapman J 1999 Mechanisms of androgen receptor activation and function. Journal of Steroid Biochemistry and Molecular Biology 69 307-313. (doi:10.1016/S0960-0760(99)00049-7)

Carruba G 2007 Estrogen and prostate cancer: an eclipsed truth in an androgen-dominated scenario. Journal of Cellular Biochemistry 102 899-911. (doi:10.1002/jcb.21529)

Celhay O, Yacoub M, Irani J, Dore B, Cussenot O \& Fromont G 2010 Expression of estrogen related proteins in hormone refractory prostate cancer: association with tumor progression. Journal of Urology 184 2172-2178. (doi:10.1016/j.juro.2010.06.089)

Cox RL \& Crawford ED 1995 Estrogens in the treatment of prostate cancer. Journal of Urology 154 1991-1998. (doi:10.1016/S0022-5347(01) 66670-9)

Culig Z 2004 Androgen receptor cross-talk with cell signalling pathways. Growth Factors 22 179-184. (doi:10.1080/08977190412331279908)

Donovan MJ, Hamann S, Clayton M, Khan FM, Sapir M, Bayer-Zubek V, Fernandez G, Mesa-Tejada R, Teverovskiy M, Reuter VE et al. 2008 Systems pathology approach for the prediction of prostate cancer progression after radical prostatectomy. Journal of Clinical Oncology 26 3923-3929. (doi:10.1200/JCO.2007.15.3155)

Donovan MJ, Osman I, Khan FM, Vengrenyuk Y, Capodieci P, Koscuiszka M, Anand A, Cordon-Cardo C, Costa J \& Scher HI 2010 Androgen receptor expression is associated with prostate cancer-specific survival in castrate patients with metastatic disease. BJU International 105 462-467. (doi:10.1111/j.1464-410X.2009.08747.x)

Edwards J \& Bartlett JM 2005 The androgen receptor and signaltransduction pathways in hormone-refractory prostate cancer. Part 2: androgen-receptor cofactors and bypass pathways. BJU International 95 1327-1335. (doi:10.1111/j.1464-410X.2005.05527.x)

Feldman BJ \& Feldman D 2001 The development of androgen-independent prostate cancer. Nature Reviews. Cancer 1 34-45. (doi:10.1038/ 35094009)

Guo Z, Dai B, Jiang T, Xu K, Xie Y, Kim O, Nesheiwat I, Kong X, Melamed J, Handratta VD et al. 2006 Regulation of androgen receptor activity by tyrosine phosphorylation. Cancer Cell 10 309-319. (doi:10.1016/j.ccr. 2006.08.021)

Hodgson MC, Bowden WA \& Agoulnik IU 2012 Androgen receptor footprint on the way to prostate cancer progression. World Journal of Urology 30 279-285. (doi:10.1007/s00345-011-0743-7)

Huggins C \& Hodges CV 1972 Studies on prostatic cancer. I. The effect of castration, of estrogen and androgen injection on serum phosphatases in metastatic carcinoma of the prostate. CA: A Cancer Journal for Clinicians 22 232-240. (doi:10.3322/canjclin.22.4.232)

Jemal A, Bray F, Center MM, Ferlay J, Ward E \& Forman D 2011 Global cancer statistics. CA: A Cancer Journal for Clinicians 61 69-90. (doi:10.3322/caac.20107)

Jongsma J, Oomen MH, Noordzij MA, Van Weerden WM, Martens GJ, van der Kwast TH, Schroder FH \& van Steenbrugge GJ 2000 Androgen deprivation of the PC-310 [correction of prohormone convertase-310] human prostate cancer model system induces neuroendocrine differentiation. Cancer Research 60 741-748.

Koivisto P, Kononen J, Palmberg C, Tammela T, Hyytinen E, Isola J, Trapman J, Cleutjens K, Noordzij A, Visakorpi T et al. 1997 Androgen receptor gene amplification: a possible molecular mechanism for androgen deprivation therapy failure in prostate cancer. Cancer Research 57 314-319.

Kononen J, Bubendorf L, Kallioniemi A, Barlund M, Schraml P, Leighton S, Torhorst J, Mihatsch MJ, Sauter G \& Kallioniemi OP 1998 Tissue microarrays for high-throughput molecular profiling of tumor specimens. Nature Medicine 4 844-847. (doi:10.1038/nm0798-844)

Latil A, Bieche I, Vidaud D, Lidereau R, Berthon P, Cussenot O \& Vidaud M 2001 Evaluation of androgen, estrogen (ER $\alpha$ and $E R \beta)$, and progesterone receptor expression in human prostate cancer by real-time quantitative reverse transcription-polymerase chain reaction assays. Cancer Research 61 1919-1926.

Leav I, Lau KM, Adams JY, McNeal JE, Taplin ME, Wang J, Singh H \& Ho SM 2001 Comparative studies of the estrogen receptors $\beta$ and $\alpha$ and the androgen receptor in normal human prostate glands, dysplasia, and in primary and metastatic carcinoma. American Journal of Pathology 159 79-92. (doi:10.1016/S0002-9440(10)61676-8)

Lin HK, Hu YC, Yang L, Altuwaijri S, Chen YT, Kang HY \& Chang C 2003 Suppression versus induction of androgen receptor functions by the phosphatidylinositol 3-kinase/Akt pathway in prostate cancer LNCaP cells with different passage numbers. Journal of Biological Chemistry 278 50902-50907. (doi:10.1074/jbc.M300676200)

Linja MJ, Savinainen KJ, Saramaki OR, Tammela TL, Vessella RL \& Visakorpi T 2001 Amplification and overexpression of androgen receptor gene in hormone-refractory prostate cancer. Cancer Research 61 3550-3555.

MacKenzie L, McCall P, Hatziieremia S, Catlow J, Adams C, McArdle P, Seywright M, Tanahill C, Paul A, Underwood M et al. 2012 Nuclear factor kappaB predicts poor outcome in patients with hormone-naive prostate cancer with high nuclear androgen receptor. Human Pathology 43 1491-1500. (doi:10.1016/j.humpath.2011.11.009)

Mak P, Leav I, Pursell B, Bae D, Yang X, Taglienti CA, Gouvin LM, Sharma VM \& Mercurio AM 2010 ER $\beta$ impedes prostate cancer EMT by destabilizing HIF- $1 \alpha$ and inhibiting VEGF-mediated snail nuclear localization: implications for Gleason grading. Cancer Cell 17 319-332. (doi:10.1016/j.ccr.2010.02.030)

McCall P, Gemmell LK, Mukherjee R, Bartlett JM \& Edwards J 2008 Phosphorylation of the androgen receptor is associated with reduced survival in hormone-refractory prostate cancer patients. British Journal of Cancer 98 1094-1101. (doi:10.1038/sj.bjc.6604152)

Nakamura Y, Felizola SJ, Kurotaki Y, Fujishima F, McNamara KM, Suzuki T, Arai Y \& Sasano H 2012 Cyclin D1 (CCND1) expression is involved in estrogen receptor $\beta(\mathrm{ER} \beta)$ in human prostate cancer. Prostate $\mathbf{7 3}$ 590-595. (doi:10.1002/pros.22599)

Nanni S, Benvenuti V, Grasselli A, Priolo C, Aiello A, Mattiussi S, Colussi C, Lirangi V, Illi B, D’Eletto M et al. 2009 Endothelial NOS, estrogen receptor $\beta$, and HIFs cooperate in the activation of a prognostic transcriptional pattern in aggressive human prostate cancer. Journal of Clinical Investigation 119 1093-1108. (doi:10.1172/JCI35079)

Nelles JL, Hu WY \& Prins GS 2011 Estrogen action and prostate cancer. Expert Review of Endocrinology \& Metabolism 6 437-451. (doi:10.1586/ eem.11.20)

Rochette-Egly C 2003 Nuclear receptors: integration of multiple signalling pathways through phosphorylation. Cellular Signalling 15 355-366. (doi:10.1016/S0898-6568(02)00115-8)

Ruiz C, Seibt S, Al Kuraya K, Siraj AK, Mirlacher M, Schraml P, Maurer R, Spichtin H, Torhorst J, Popovska S et al. 2006 Tissue microarrays for comparing molecular features with proliferation activity in breast cancer. International Journal of Cancer 118 2190-2194. (doi:10.1002/ijc. 21581)

Ruiz C, Holz DR, Oeggerli M, Schneider S, Gonzales IM, Kiefer JM, Zellweger T, Bachmann A, Koivisto PA, Helin HJ et al. 2011 Amplification and overexpression of vinculin are associated with increased tumour cell proliferation and progression in advanced prostate cancer. Journal of Pathology 223 543-552. (doi:10.1002/path.2828) 
Taplin ME, Bubley GJ, Shuster TD, Frantz ME, Spooner AE, Ogata GK, Keer HN \& Balk SP 1995 Mutation of the androgen-receptor gene in metastatic androgen-independent prostate cancer. New England Journal of Medicine 332 1393-1398. (doi:10.1056/ NEJM199505253322101)

Urbanucci A, Sahu B, Seppala J, Larjo A, Latonen LM, Waltering KK, Tammela TL, Vessella RL, Lahdesmaki H, Janne OA et al. 2012 Overexpression of androgen receptor enhances the binding of the receptor to the chromatin in prostate cancer. Oncogene 31 2153-2163. (doi:10.1038/onc.2011.401)

Visakorpi T, Hyytinen E, Koivisto P, Tanner M, Keinanen R, Palmberg C, Palotie A, Tammela T, Isola J \& Kallioniemi OP 1995 In vivo amplification of the androgen receptor gene and progression of human prostate cancer. Nature Genetics 9 401-406. (doi:10.1038/ ng0495-401)

Waltering KK, Helenius MA, Sahu B, Manni V, Linja MJ, Janne OA \& Visakorpi T 2009 Increased expression of androgen receptor sensitizes prostate cancer cells to low levels of androgens. Cancer Research 69 8141-8149. (doi:10.1158/0008-5472.CAN-09-0919)

Wilding G, Chen M \& Gelmann EP 1989 Aberrant response in vitro of hormone-responsive prostate cancer cells to antiandrogens. Prostate 14 103-115. (doi:10.1002/pros.2990140204)

Wright ME, Tsai MJ \& Aebersold R 2003 Androgen receptor represses the neuroendocrine transdifferentiation process in prostate cancer cells. Molecular Endocrinology 17 1726-1737. (doi:10.1210/me.2003-0031)

Yuan TC, Veeramani S, Lin FF, Kondrikou D, Zelivianski S, Igawa T, Karan D, Batra SK \& Lin MF 2006 Androgen deprivation induces human prostate epithelial neuroendocrine differentiation of androgen-sensitive LNCaP cells. Endocrine-Related Cancer 13 151-167. (doi:10.1677/erc.1. 01043)

Zellweger T, Ninck C, Mirlacher M, Annefeld M, Glass AG, Gasser TC, Mihatsch MJ, Gelmann EP \& Bubendorf L 2003 Tissue microarray analysis reveals prognostic significance of syndecan-1 expression in prostate cancer. Prostate 55 20-29. (doi:10.1002/pros.10209)

Received in final form 10 April 2013

Accepted 11 April 2013

Made available online as an Accepted Preprint

11 April 2013 http://erc.endocrinology-journals.org DOI: 10.1530/ERC-12-0402
(C) 2013 Society for Endocrinology Printed in Great Britain
Published by Bioscientifica Ltd. 